\title{
The controversy regarding the need for hormonal treatment in boys with unilateral cryptorchidism goes on: a review of the literature by B. Ludwikowski and R. González
}

\author{
Faruk Hadziselimovic
}

Received: 10 March 2012 / Accepted: 4 April 2012 / Published online: 21 April 2012

(C) Springer-Verlag 2012

Sir,

In their review, Ludwikowski and González [5] discouraged the use of hormones in unilateral cryptorchid boys because (1) the paternity rate is normal in men with unilateral undescended testes treated with surgery alone, (2) the efficacy of hormonal treatment in inducing testicular descent is low, (3) the cost of the treatment is considerable, and (4) there are potential adverse effects associated with treatment.

However, despite successful surgery, azoospermia is 25 times more common in unilateral and 80 times more common in bilateral cryptorchidism in comparison with the control population [2]. Thus, cryptorchidism is one of the main etiologic causes of non-obstructive azoospermia in man [1]. Interestingly enough, in unilateral cryptorchid males, no significant differences in frequency of azoospermia was observed irrespective of the treatment modalities used (untreated, $12 \%[16 /$ 134]; HCG treated, $12.6 \%$ [25/198]; surgically treated, $10.3 \%$ [198/1773] [2]. Notably, if patients who were at increased risk of infertility (those lacking Ad spermatogonia in their testes) received treatment with buserelin, normal spermiograms were observed in $86 \%$ of subjects [3]. Moreover, more than one third of males in the high infertility risk group will develop azoospermia ([8/21] [6]; [20/61]) [4] while none (0/50) $(p<0.000001)$ of the males with identical testicular pathology at surgery who received treatment with buserelin following orchidopexy developed azoospermia.

Therefore, since the endocrinopathy of mini-puberty is responsible for ensuing infertility in cryptorchidism, postsurgical hormonal treatment is highly recommended in cryptorchid boys who have early successful orchidopexy but remain at risk of infertility. Finally, hormonal treatment has been the choice of initial treatment (before surgery) in Europe for years. It abrogates the need for subsequent surgery, and for non-responders, it facilitates orchidopexy and contributes considerably to reducing the incidence of unilateral and bilateral complete post surgical testicular atrophy.

\section{References}

1. Fedder J, Crüger D, Oestergaard B, Petersen GB (2004) Etiology of azoospermia in 100 consecutive non-vasectomised men. Fertil Steril 82:1463-1464

2. Hadziselimovic F, Hadziselimovic NO, Demougin P, Oakeley EJ (2011) Testicular gene expression in cryptorchid boys at risk of azoospermia. Sex Dev 5:49-59

3. Hadziselimovic F (2008) Successful treatment of unilateral cryptorchid boys risking infertility with LH-RH analogue. Int Braz J Urol 34:319-326

4. Hadziselimovic F, Höcht B, Herzog B, Buser MW (2007) Infertility in cryptorchidism is linked to the stage of germ cell development at orchidopexy. Horm Res 68:46-52

5. Ludwikowski B, González R (2012) The controversy regarding the need for hormonal treatment in boys with unilateral cryptorchidism goes on. A systematic review of the literature. Eur J Pediatr (Epub ahead of print)

6. Nistal M, Paniagua R, Riestra ML, Reyes-Múgica M, Cajaiba MM (2007) Bilateral prepubertal testicular biopsies predict significance of cryptorchidism-associated mixed testicular atrophy, and allow assessment of fertility. Am J Surg Pathol 31(8):1269-76

F. Hadziselimovic $(\bowtie)$

Kindertagesklinik,

Liestal, Switzerland

e-mail: faruk@magnet.ch 